4. Енциклопедія освіти / гол. ред. В.Г. Кремень. - К., 2008.

5. Роджерс К. Клієнт-центрована терапія. - М. : Рефл-бук; К. : Ваклер, 1997. - 320 с.

6. Философский энциклопедический словар / Редкол.: С.С. Аверинцев, Э.А. Араб-Оглы, Л.Ф. Ильичев и др. - 2-е изд. - М.: Сов. энциклопедия, 1989.

DOI https://doi.org/10.30525/978-9934-26-114-5-19

\title{
СПІЛКУВАННЯ У СТРУКТУРІ ФОРМУВАННЯ ФАХОВИХ ПЕДАГОГІЧНИХ ЗДІБНОСТЕЙ ВЧИТЕЛЯ ФІЗИЧНОї КУЛЬТУРИ
}

\author{
Григоренко Г. В. \\ кандидат педагогічних наук, \\ доцент кафедри методик викладання \\ спортивно-педагогічних дисциилін \\ ДВНЗ «Донбаський державний педагогічний університет» \\ Григоренко Д. П. \\ асистент кафедри методик викладання \\ спортивно-педагогічних дисциплін \\ ДВНЗ «Донбаський державний педагогічний університет» \\ м. Слов'янськ, Украӥна
}

Сучасний педагог - це активна творча особистість 3 твердою життєвою позицією, яка здійснює свою діяльність під впливом дієвих методів навчання 3 широким використанням інтерактивних педагогічних технологій, особистісно орієнтованого підходу у освітньому процесі та мотивів, серед яких домінуючими є соціально значущі. Спілкування людини, як духовно-соціальна категорія, саме той універсальний суспільно-педагогічний інструмент пізнання та засвоєння людиною історичного, культурного, професійно-трудового досвіду, на засадах якого особистість формується, гармонійно розвивається, самовдосконалюється, соціально стверджується та самореалізується. Не має сумніву в тому, що категорія «спілкування» є визначальною в процесі фахової підготовки педагогічних кадрів взагалі, особливо, у галузі фізичної культури.

Педагогічне спілкування передбачає, насамперед, основу успішної результативної діяльності педагога. Проблеми та питання 
педагогічного спілкування, оптимальні шляхи їх подолання, методичні та практичні рекомендації висвітлювали у своїх науково-педагогічних дослідженнях I. Бех, О. Бодальов, Т. Василишина, В. Григоренко, Н. Кузьміна, О. Леонтьєв, Л. Лубишева, Б. Максимчук， Т. Матвійчук, Н. Ольшанська， Т. Петровська， 3. Підручна， Б. Шиян. Узагальнений висновок їх робіт полягає у необхідності системної підготовки майбутніх вчителів до вміння спілкуватися з учнями.

Спілкування як базова категорія поведінки та діяльності людини, позиціонується в ii свідомості, обумовлюючи тим самим «можливість успішно і цілеспрямовано реалізувати комплекс заходів щодо формування гармонійно розвиненої особистості» [1, с. 53]. За аргументованим твердженням І.Беха, «це пов'язано з тим, що спілкування, поряд з працею, являє собою основний спосіб існування людини, основну умову ії виховання і розвитку, засвоєння суспільного досвіду» [1, с. 53], а також фахової підготовки педагогічних кадрів для національної освіти, яка орієнтується на широке впровадження інтерактивних освітньо-виховних технологій. Спілкування ми розуміємо як структуру спільної діяльності суб'єктів суспільно-соціальної практики та потужний чинник фізичного, психічного, духовного та соціального розвитку особистості. Це обумовлює розвиток однієї із базових потреб до взаємодії, співпраці, задоволення якої органічно пов'язане 3 неодмінним досягненням психоемоційного комфорту людини, відчуттям захищеності та особистісної значущості.

Вибіркове опитування студентів 1-2 курсів (n=27) факультету фізичного виховання показало, що 100 \% з них вважають необхідним навчання основам педагогічного спілкування; $88,8 \%$ звертають увагу на раціональність проведення тренінгів, семінарів 3 провідними фахівцями для поповнення знань й набуття практичних навичок з означеної теми; 44,4 \% передбачають складнощі у спілкуванні з учнями під час проведення уроків; 11,0\% не вбачають проблем у спілкуванні.

Ми акцентуємо увагу викладачів закладів освіти на необхідність врахування основних функцій спілкування під час підготовки та проведення занять: - інформаиійно-комуникативна функиія - передача та засвоєння студентами професійно-педагогічної інформації; експресивно-комунікативна функиія - обмін почуттями, емоціями, емпатія, співпереживання; - регулятивно-комунікативна функиія зміст поведінки студентів, рівень взаєморозуміння суб'єктів фахової підготовки; - інструментально-синдикативна функиія - механізми передачі інформації та об'єднання зусиль суб'єктів фахової підготовки; - соціалізуюча функція - формування особистості майбутнього педагога. 
Звертаємо також увагу й на системні ознаки спілкування, які за твердженням В.Григоренка [2], включають: - комунікативну складову відображає зміст взаємодії, співпраці, взаємотворчості, взаємопідтримки, фахового визнання та ідентифікації; - інтерактивну складову відображає форми і типи співпраці суб'єктів фахової підготовки в існуючих системах суб'єкт-суб'єктних взаємовідносин, співпраці, співтворчості: «студент-викладач», «студент-студент», «студент-мала група», «викладач-мала група», «студент-середовище фахової підготовки», «викладач-середовище фахової підготовки», «викладач-викладач»; - периептивну складову - відображає особливості психоемоційного та духовно-естетичного сприйняття та уявлення суб'єктів фахової підготовки відносно один одного; - регулятивно-емоційну складову відображає мотиви і потреби, їх інтенсивність та спрямованість в процесі особистісно орієнтованої фахової підготовки студентів (регулятивна інформація, емоційна інформація, інформація адекватності змісту фахової підготовки потребам студентів).

В процесі фахової підготовки майбутніх педагогів необхідно забезпечувати формування у них здібностей до спілкування зі своїми вихованцями. Здібності педагога до спілкування, як зазначає I. Бех, розглядаються «провідною детермінантою всієї системи психічних процесів, станів, властивостей людини, спілкування виступає основним засобом, за допомоги якого здійснюються виховні впливи на особистість, відбувається, за необхідності, оптимізація і корекція іiі психологічного стану. У цьому зв'язку особистість необхідно розуміти як продукт і результат індивідуального досвіду ії спілкування з іншими людьми» [1, с. 53]. Спілкування суб'єктів професійно-педагогічної підготовки у закладах вищої освіти є підгрунтям суб'єкт-суб'єктних взаємовідносин у вище зазначених системах, що забезпечують інтерактивне формування особистості педагога в освітній та фізкультурнооздоровчій діяльності .

Надана узагальнена характеристика категорії «спілкування» в структурі фахової підготовки студентів дозволила реалізувати його властивості, як низку комунікативних завдань (організаційні, контролюючі, регулюючі, стимулюючі, корегуючі), що системно забезпечують здійснення вербального спілкування, організації зворотнього психоемоційного зв'язку між суб'єктами педагогічного спілкування.

Викладач університету удосконалює організаційно-педагогічні підходи до використання інтерактивних форм організації навчального процесу з фахових дисциплін, вивчення яких забезпечує розвиток у студентів професійно-педагогічних здібностей, моральної, духовної сфери їх особистості, вирішує проблему ефективності адаптації 
педагогів до реальних умов самостійної діяльності в освітній та фізкультурно-оздоровчій системі суспільства. Викладачем створюються умови прогнозування, партнерства в реалізації навчальної діяльності з певної дисципліни фахової підготовки. Результатом такої співпраці студентів і викладача $\epsilon$ встановлення таких форм співтворчості, як дебати, дискусія, діалог, обговорення проблемних питань освітнього процесу, його інтеріоризація на рівні свідомості суб'єктів фахової підготовки.

Досить ефективним $є$ метод взаємонавчання, який передбачає таку форму співпраці, коли один студент в процесі навчальної діяльності виконує функції викладача, а інші знаходяться в ролі учня. В цій ситуації дієвими формами інтерактивної діяльності студентів $€$ організації діад, тріад та мікрогруп (4-5 осіб). На занятті моделюється діяльність вчителя, контролюється діяльність малих груп, в них стимулюється взаємодопомога, взаємний обмін інформацією, знаннями, досвідом. Значно підвищується рівень спілкування, створюється позитивний психоемоційний клімат, покращуються міжособистісні стосунки студентів і викладача, що обумовлює формування у них позитивної самооцінки, яка є структурним психоемоційним компонентом мотиваційної сфери професійно-педагогічної підготовки. Удосконалення суб'єкт-суб'єктних відносин в освітньо-виховному процесі викладач повинен реалізовувати через пізнавально-виховне спілкування студентів шляхом оптимального моделювання (планування) його цільового, змістовного, організаційно-технологічного компонентів.

Метод пробних переміщень передбачає створення умов, які максимально наближені до існуючих посад у педагогічному колективі освітніх закладів, посадових обов'язків та дають змогу студенту «виконувати» функції відповідно посаді, на яку його «призначено» або переміщено. Студенти набувають та вдосконалюють управлінські навички, навички професійного спілкування, вирішення життєвих ситуацій, спілкування з батьками, які можуть особисто продемонструвати під час проведення фрагменту лекції, практичного заняття.

Таким чином, основним педагогічним інструментом взаємодії вчителя фізичної культури, викладача, тренера $є$ спілкування, від якості якого прямо залежить ефективність їх фахової діяльності.

\section{Література:}

1. Бех І. Виховання особистості: У 2 кн. Кн.2: Особистісно орієнтований підхід: науково-практичні засади. К. : Либідь, 2003. 344 с.

2. Григоренко В.Г., Григоренко Г.В. Особистісно орієнтовані педагогічні технології фахової підготовки вчителя фізичної культури: 80 
посібник для студентів вищих навчальних закладів. Слов'янськ : Вид-во Б. І. Маторіна, 2017. 233 с.

3. Петровська Т.В. Майстерність спортивного педагога: навч. посіб. К.: НУФВСУ, вид-во «Олімп. л-ра», 2015. 184 с.

4. Цьось А. В., Балахнічова Г. В., Заремба Л. В. Сучасні технології викладання спортивних дисциплін: навч. посібник. Луцьк : ВНУ ім. Лесі Українки, 2010. 132 с.

DOI https://doi.org/10.30525/978-9934-26-114-5-20

\title{
ПРОЦЕС «ВМОТИВОВАНОЇ СОЦІАЛІЗАЦЇ̈» УЧНІВ СЕРЕДНЬОГО ШКІЛЬНОГО ВІКУ В УМОВАХ ДИСТАНЦІЙНОГО НАВЧАННЯ
}

\author{
Ільницька Л. В. \\ докторант \\ Інститут проблем виховання НАПН Украӥни \\ м. Київ, Україна
}

Новітні виклики нашого часу, що пов'язані із сучасною епідемологічною ситуацією, яка суцільно видозмінює звичні процеси входження учнів у запланований ритм шкільного життя, виявляє найактуальніші акцентні «площини дистанційної взаємодії», як нетипової кореляції тієї соціалізації, яка належним чином дозволяє емоційно відкривати оточуюче різноманіття та безбар'єрно контактувати 3 однолітками, навчатися, а також невимушено переймати досвід при проявах поважного ставлення до наставників і вчителів та, що, в першу чергу, залишається важливим - органічно відкривати власну індивідуально-особистісну сутність у природному для шкільного віку середовищі знань.

Термінологічна складова «площини дистанційної взаємодії» укорінена у технологічний світ «мобільного темпоритму». Швидкісний інтернет зв'язок започаткував характерний темп обміну думками i враженнями, що стало популярним ще до часів пандемічних викликів спілкування на відстані за допомогою соціальних мереж відкрило інший знаково-символічний поступ здебільшого емоційної дієвості. Самовизначення в цих умовах - це легкість миттєвого потрапляння у середовище потрібної контактної групи. Готовність спілкуватися саме таким чином - це демонстрація вмотивованої «одномоментної 